\title{
The Police Use of Social Media: Transformation or Normalisation?
}

\author{
Karen Bullock
}

Department of Sociology, University of Surrey

E-mail:k.bullock@surrey.ac.uk

There has been optimism that social media will facilitate citizen participation and transform the communication strategies of public organisations. Drawing on a case study of the public police in England, this article considers whether social media are transforming or normalising communications. Arguing that social media have not yet served to facilitate interaction between constabularies and citizens in the ways that have been proposed and desired, the article considers factors that structure the transformative potential of social media. It is argued that the uses of social media are mediated by the existing organisational and occupational concerns of the police. This article reveals how an interplay of organisational, technological and individual and cultural dynamics come together to shape how social media are used in constabularies. Embedding social media into police communications is challenging and the technology itself will not bring about the organisational and cultural changes needed to transform police-citizen engagement.

Key words: Communication strategies, public policing, social media.

\section{Introduction}

Social media have been heralded as a way of engendering openness, transparency and citizen participation in public policing. Relatively little is known, however, about how social media are understood by officers and staff and incorporated into their communication strategies, and how social media function to facilitate, or otherwise, citizen participation (Brainard and McNutt, 2010; Crump, 2011; Schneider, 2016). This is important because it is understood that the impact of new technologies in the police environment is contingent on a range of internal and external driving forces and counter forces (Chan, 2003). Indeed, studies have revealed that social media are not currently transforming the communicative practices of police services in the ways that proponents have proposed (Brainard and McNutt, 2010; Crump, 2011; Lieberman et al., 2013; Grimmelikhuijsen and Meijer, 2015). This article examines the nature of police communication on social media and the factors which shape their transformative potential. Drawing on Manning (1992, 2008), it is argued that the police use of social media is mediated by organisational and occupational concerns. The contribution of this article lies in its explication of the ways that social media have been understood by officers and incorporated into policing routines. In so doing, the ways that the transformative potential of social media have been muted are revealed. I start by exploring the communicative practices of the public police and situating social media within them. 


\section{Internet, social media and democratic policing}

The impetus for initiatives in e-democracy can be traced to the early 1990s, the era when internet use started to proliferate throughout the Western world (Chadwick and May, 2003; Wright, 2006; Chadwick, 2009; Ellison and Hardey, 2014). There was, at this time, optimism that the internet might revive democratic structures. Optimism which can be understood in the context of a purported 'crisis of democracy', a democratic deficit characterised by low citizen participation in political institutions and declining trust (Stoker, 2006; Wright, 2006; Whiteley, 2012). Oft-framed as a means of reviving 'Athenian' participatory democracy Web 1.0, the first stage in the evolution of the World Wide Web (WWW), was certainly hailed by some as a way of reinvigorating decision-making. As empirical work started to reveal that officials and politicians were reluctant to adopt the burgeoning online tools, that citizen participation was low and, that rather than offering new avenues for participation, was attracting those who were already engaged in political processes, early optimism was gradually replaced by a degree of pessimism (Chadwick and May, 2003; Di Gennaro and Dutton, 2006; Wright, 2006; Chadwick, 2009; Loader and Mercea, 2011). Since these early days the capacity of the internet to engender interaction and debate between citizens, officials and politicians has been transformed by the diffusion of Web 2.0 platforms. Emphasising user-generated content, these social media are founded in, and support the principles of, openness and transparency, and, in principle at least, facilitate dialogue, collaboration and co-creativity between users (Macnamara and Zerfass, 2012; Lipschultz, 2015). There has been new waves of optimism that networks such as Facebook, Twitter, YouTube, Snapchat along with Wikies and the blogosphere will facilitate dialogue and debate between citizens, officials and politicians and come to revive political structures (Loader and Mercea, 2011; Ellison and Hardey, 2014; Loader et al., 2014). As Ellison and Hardey (2014: 26) put it 'the extraordinary spread of internet usage combined with the changing practices of use - specifically social networking - suggests that there is now serious future potential for the enhancement of online participation'. Such optimism translates into public policing, for reasons I will briefly consider.

There has been systemic pressure on constabularies to facilitate openness, transparency and citizen participation in police decision-making. From smoothing ruptures between the police and citizens (Scarman, 1981; Lea and Young, 1993; Sklansky, 2005), to implanting business principles into decision-making (Loader, 1999; Loader and Walker, 2001; Bullock, 2014), to providing a means through which citizens can express their preferences for the nature of crime control at the local level (McLaughlin; 2005; Bullock, 2014), opening up constabularies has been viewed as a way of protecting citizens, improving the quality of the service and initiating a means of holding officers to account. It follows that constructing constabularies as open, transparent and democratic has been a primary aim of contemporary police communication strategies. There have been a number of reasons for promoting citizen participation in public policing. However, following Scarman (1981), historically one form of consultative practice has dominated: the police-community meeting. Whilst omnipresent, many studies have revealed that police-community meetings have done little to transform police communication. Police-community meetings have suffered from low participation, those citizens who did participate were typically white, middle-class and already embedded in the political establishment, and meetings have generally provided a forum for officers to broadcast 
information and to rubber stamp decisions that had already been made by constabularies rather than to stimulate debate and dialogue between officers and citizens (Keith, 1988; Stratta, 1990; Hughes, 1994; Elliott and Nicholls, 1996; Harfield, 1997; Jones and Newburn, 2001; Myhill et al., 2003). In short, traditional forms of community engagement activity have done little to promote the desired outcomes of increased participation, transparency and accountability.

Moving police communication from the physical to the virtual, social media have been presented as a way of circumnavigating the aforementioned problems and affording a mechanism through which constabularies might engage with citizens and communities and, in so doing, present themselves as open, participative and democratic (Fink and Zerfass, 2010; Avery and Graham, 2013). The use of social media by constabularies to engage with citizens and other constabularies has been a marked trend in recent years. This trend is best understood within the context of the reinvigoration of community policing in the UK and around the globe. The practices of community policing seek to facilitate interaction between police officers and citizens. In the interests of promoting legitimacy and controlling crime, the aim of community policing is to encourage citizens to take individual and collective responsibility for crime control at the local level and to marry policing and community priorities (Manning, 1991; Barlow and Barlow, 1999; Maguire and Wells, 2002; Bullock, 2014). It follows that social media have been adopted by community policing teams across the USA, Australia and Northern Europe (COPS, 2013; The Police Foundation, 2014). Indeed, of the some 2,000 official police Twitter accounts operating in the UK at the time of writing about half are thought to be community policing accounts (Ashby, n.d.). Thus community policing teams are supposed to use social media to reach out to citizens and communities, to engage them in debate and to listen to and act upon their concerns. It has been hoped that social media will provide an efficient technological response to an enduring conundrum in public policing - that of how to stimulate communication between officers and citizens.

For all the optimism that social media will expedite dialogue and debate between citizens and officers, large-scale analyses of social media content have started to demonstrate that police communication on social media is one-way (Brainard and McNutt, 2010; Crump, 2011; Lieberman et al., 2013; Grimmelikhuijsen and Meijer, 2015). Research has indicated that social media are primarily used by constabularies to make requests for assistance, to circulate police-relevant crime and incident information and to give crime prevention tips rather than to facilitate interaction, debate and collaborative problem-solving. Observations which fall in line with research from the public (Wright, 2006; Avery and Graham, 2013; Ellison and Hardey, 2014) and private (Jones et al., 2004; Preece et al., 2004; Joyce and Kraut, 2006) spheres more generally. The qualitative research on which this article is based did not systematically quantify the nature of police generated social media. It is worth briefly noting, however, that the reflections of participants broadly chimed with this wider body of evidence. Asked to reflect on this matter, participants revealed a degree of complexity. They drew attention to how the aim of using social media certainly was to transcend one-way communication in principle and some participants were adamant that social media could facilitate police-citizen interaction, and gave examples of this occurring in practice. Reflecting observations that the Internet might enable citizens to forge direct links with officials and in so doing engender transparency and foster forms of accountability which would not have been previously been attainable (Loader and Mercea, 2011; Ellison and Hardey, 
2014; Loader et al., 2014), some participants also thought that social media could improve officer responsiveness to the concerns of citizens. Even so, reflecting either on their own experiences or those of others, many participants drew attention to how this represented the exception rather than the rule, and were sometimes rather pessimistic about what could realistically be achieved.

In sum, the weight of research is indicating that social media are not transforming the nature of routine police-citizen communications. Indeed, research has demonstrated that new technologies have had less effect on police practices than has been advocated (a result of how they are mediated by the existing organisational and occupational concerns of the police) and that the impact of police technologies can be to reproduce existing orders rather than to produce changes (Manning, 1992, 2008). Technology at once shapes organisations and occupations and is shaped by them (Manning, 1992; Chan, 2003). As Chan (2003) notes, technological changes should be understood via an interpretative rather than deterministic lens. An interpretative lens highlights how organisational members and the organisational context influences the use of technologies, as they are introduced into organisations in ways that are not always easy to predict. Thus, the way technology is used in police organisations is influenced by the nature of the technology itself, the meaning officers and staff ascribe to technology and wider organisational processes and practices. Consideration of these matters as they apply to the introduction of social media into the communication practices of constabularies is the primary aim of this article. Let us turn our attention now to the design and parameters of the present study.

\section{Research design and methodology}

This article draws on the analysis of thirty-two interviews conducted with officers and police staff in five constabularies in England in 2014. These participants were generated through purposive sampling. As 'key informants' (Parsons, 2008), participants were known to have experience and knowledge of social media and the way that they are understood and employed by constabularies and officers. Participants fell into three broad groups. The first group $(N=10)$ comprised officers and staff who had made use of social media over a period of time. Often pioneers within their organisation, they were typically early adopters of social media who had experimented extensively with it. The second group $(N=10)$ held relevant police managerial roles at the local and/or national level for social media and/or community policing. The third group $(N=12)$ comprised communications and public relations (PR) professionals. These participants managed and coordinated physical and virtual communications on behalf of constabularies and were responsible for developing the infrastructure to do so. Participants were identified through a two-fold approach. First, through 'snowball sampling' (Chromy, 2008). Existing participants nominated additional participants from among their networks of colleagues and connections. Second, an advert was placed on a College of Policing online collaboration tool that enables knowledge and information sharing across constabularies in England and Wales. ${ }^{1}$ Participants were asked to reflect on the organisational benefits generated through social media and the factors which shaped their use. Themes were teased out and are discussed in the forthcoming sections in light of extant literature from both the public and private sectors. Following the aforementioned connection between community policing and social media, focus was on the role of the latter in facilitating citizen engagement as opposed to their role 
in the generation of intelligence or police investigations (see COPS, 2013). The article also focuses on the official, rather than personal, use of social media (see Goldsmith, 2015; Schneider, 2016). The emphasis is on police use of Twitter. This emphasis was not intentional; however, it soon became clear that Twitter was the primary platform used by officers and staff - something which has implications for the nature of communication, as this article will demonstrate. Let us now consider how the interaction of organisational, technological, and individual and cultural dynamics influence the nature of police-citizen communication on social media and the implications for the transformative potential of social media.

\section{The dynamics of police-citizen communication on social media}

\section{Organisational dynamics}

Taken together, a series of organisational dynamics - which included (1) the attitudes and approach of police leaders (2) organisational responses to risk (3) strategy and (4) the nature of the infrastructure established to support users of social media - have influenced how officers use social media. Matters which are unpicked in the forthcoming sections.

Accounts indicated that the way that police officers use social media to communicate with citizens is influenced by the attitudes and approach of police leaders. Where chief officers are supportive of officer use of social media as a communicative tool, and, pertinently, where they are proactively exploiting and promoting social media themselves, application by the rank and file was thought to be stimulated. Participants reported that such sponsorship by chief officers acts to subdue any fears that officers may have about communicating in this way, and reinforces the principle that social media should form an integral part of contemporary police communications. However, accounts also indicated that whilst some police leaders were supportive of officer use of social media and utilised social media themselves to communicate with citizens, such support and application were not unanimous (see also Crump, 2011). Instead, accounts indicated that some leaders were cautious about officer use of social media or, indeed, opposed their routine use. Whilst the perspectives of chief officers were not incorporated into this research, participants indicated that opposition is born of lack of clarity about the value of social media within the organisation and concerns about organisational risk. In respect of the former, the accounts of participants indicated that some chief officers struggle to see a role for social media within the organisation, perhaps because they are unfamiliar with the relatively new and ever-evolving technology. More specifically, participants indicated that some chief officers may view social media as a time consuming distraction for officers and staff, a concern widely shared by senior managers in other organisations (Fink and Zerfass, 2010). Jovial comments such as 'you can get obsessed with it' (INT18) and 'it can take over your life' (INT23) notwithstanding, it is worth noting that participants stated that using Twitter was not generally time consuming for officers. This is a function of the configuration of the technology and the way it is used by officers and staff. In respect of the latter, accounts strongly suggested that concerns about security and reputational risk are commonly expressed by chief officers. From disclosing sensitive or personal information obtained by constabularies, to divulging operational tactics, to revealing thoughtless or even offensive attitudes, social media potentially pose risks to the security, effectiveness and reputation of constabularies and officers therein (ACPO, 2013; Goldsmith, 2015). 
Whilst participants indicated that complaints about the nature of communication on official social media channels are unusual, they also drew attention to how concerns about risk are nevertheless pervasive, a point that is considered in more detail below.

Research has demonstrated that there are tensions within public and private organisations regarding the role of social media (Avery and Graham, 2013; Fink and Zerfass, 2010; Macnamara and Zerfass, 2012). On the one hand, social media have been widely held to be a way of promoting the dissemination of information and increasing the ability of organisations to interact with 'consumers' in novel ways. On the other hand, it is difficult for organisations to control who uses social media and the nature of the content disseminated on them. This lack of control underscores the widely held concern that social media present organisational risk. Indeed, because corporate reputation is viewed as fragile and easily damaged by any scandal and misconduct revealed on social media, loss of control of messages is seen as a major risk by communications and PR professionals (Fink and Zerfass, 2010; Macnamara and Zerfass, 2012; Lee and McGovern, 2013). Whilst such concern seems to be widespread, it might be compounded in constabularies. This is because the communications practices of constabularies have traditionally been tightly proscribed, in the context that officers are entrusted with upholding the law and officers are bound by legal and procedural regulations (Brainard and McNutt, 2010; Lee and McGovern, 2013).

The ways that the police organisation responds to this tension influences the nature of communication on social media. Participants in the present study noted that communications and PR officials apply, or seek to apply, 'different levels of organizational control and laissez faire' (INT5). This control is most clearly revealed in the decisions regarding who has access to which kinds of official police Twitter accounts. Community policing Twitter accounts tend to be established and operated either on behalf of named, clearly identifiable individuals or on behalf of teams of officers. Fundamentally aimed at controlling communications and reducing risk, some communications officials do not allow officers to set up individual official Twitter accounts, or alternatively they tightly restrict access to them. The more anonymous team accounts are preferred by some communications and PR officials because - operated by a collective rather than an individual - they are seen to afford the organisation a greater degree of control. Since communication via social media can falter when officers move vertically or horizontally within the organisation, they also facilitate a degree of continuity of communication over time. Restricting access to individual accounts has been seen as a way of resolving the dilemma of 'succession planning'. Exerting such control has, however, influenced the timbre of communications. Participants consistently drew attention to how the 'personal' communication associated with the individual accounts may be effective in engaging citizens in ways that the 'corporate' communication more associated with the team accounts may not. Many participants in the present study agreed that to facilitate engagement, communicative practices should be pushed down to the micro level. However, they also accepted that doing so might represent a risk for the organisation as it would be less able to control the content of communication. Accordingly, there would seem to be a tension between a need for organisational control of communications and the generation of engaging content that leads to citizen participation.

Strategy is a further organisational feature which has shaped the development of officer use of social media and influenced the nature of communicative practices. 
Constabularies in the UK began experimenting with Twitter in 2008, experiments which were initially associated with entrepreneurial individuals who received varying degrees of official support (Crump, 2011). Participants in the present study agreed that the use of social media grew organically with little direction and that the strategies to structure the use of social media followed, rather than informed, their development. 'It felt like the right thing to do so we went on and did it, after we did it and learnt lessons we went back and properly put a formal strategy in place', noted one participant (INT10). Indeed, limited strategic direction has characterised the development and use of the internet by private and public organisations more widely (Wright, 2006; Macnamara and Zerfass, 2012; Avery and Graham, 2013). This 'improvised' approach may start to explain why the overall objectives of utilising social media are not always clear and, in fact, seem at times to be in conflict with one another. It also starts to explain why there is a great deal of variation - in terms of organisational expectations of social media, individual capacity to engage with the technology and the quality and pitch of the content - between and within constabularies, as the technology is understood and applied differently by officers and staff who enjoy more, or less, organisational support and access to resources.

Certainly, the availability and quality of support for officers who wish to engage citizens via social media have played a role in shaping their use. Previous research has demonstrated that infrastructure - for instance supervision and training - to support technological innovation within police organisations has often been missing (Manning, 2001). Reflecting this, the infrastructure to support officer's use of social media was generally thought to be weak. Whilst policies, guidance and training are available, accounts of participants in the present study indicated that they have been of limited use in influencing how officers understand and use social media. The result is that officers learn how to communicate on social media experientially through 'trial and error' (INT9). These observations echo the experiences of users of social media in other organisations (Macnamara and Zerfass, 2012). In fact, the situation might be somewhat inevitable. Whilst officers and staff clearly ask for guidance, participants tended to agree that it is difficult for the organisation to provide the formal guidance needed. Participants drew attention to the intuitive nature of social media, which is generally guided by instinct rather than formal instruction (see also Schmidt, 2013). Guiding officers towards good practice in an ever-changing virtual world is clearly challenging. Moreover, doing so might actually influence the tone of communication on social media. Participants drew attention to a risk that over prescription will produce monotonous communication, which itself does little to engage citizens.

\section{Technological dynamics}

The Information Communications and Technology (ICT) infrastructure, cultures of ICT departments and the dominant social media platform utilised by constabularies and officers have all played a role in shaping the nature of communication on social media. Participants in the present study drew attention to how police ICT are chronically under resourced and that the introduction of social media platforms, which are generally free, open and require light programming, is at odds with the established culture of ICT development within constabularies which tends to be cautious, security conscious and highly risk adverse (see also Crump, 2011; London Assembly, 2013). A consequence is that officers have limited access to both static and mobile ICT at work - a situation which 
participants indicated can undermine the routine use of social media (see also London Assembly, 2013). Access to mobile ICT was thought by participants to be particularly important in the community policing context. To use social media in an office environment was thought to distract officers from the raison d'etre of their role - to be visible and available in the community engaging with citizens - and to undermine its value as a communication tool. Indeed, participants indicated that where officers are not able to communicate on social media whilst out of the office environment, they are less likely to do so at all. Given that at the present time many officers do not have access to official mobile technology, participants indicated that the use of personal devises was common. In fact, participants drew attention to what was sometimes seen as a paradoxical situation. Whilst officers have become used to utilising mobile ICT in many ways within their private lives, this did not readily translate into their working lives (see also Tanner and Meyer, 2015). In turn, participants drew attention to how any investment in mobile ICT by constabularies (and some have invested) paid dividends for officers.

The dominant platform used by officers and staff - Twitter - also shapes the nature of police communication and its transformative potential. Twitter certainly supports dialogue and deliberation in principle (Halavais, 2013; Schmidt, 2013). However, participants suggested that Twitter was not necessarily conducive to police-citizen interaction and collaboration in practice, especially when compared with other social media platforms (see also Crump, 2011). This is because Twitter - which facilitates the dissemination of short (140-character) messages - is thought to be better suited to 'broadcasting' police relevant information than facilitating interaction between officers and citizens (see also Crump, 2011). Given that community policing teams have been expected to use social media to engender engagement, this raises questions about why Twitter has become so dominant. Its dominance might result from the failure to situate police use of social media within an overarching communications strategy and from the limitations of the police ICT infrastructure. However, a primary explanation for the dominance of Twitter lies in its manageability for officers and staff, especially when compared to other platforms. Twitter appears to have become the preferred platform less because of its value as an engagement tool and more because it is straightforward and relatively quick for officers to use. There is a risk that establishing networks of Twitter accounts has become an end in itself rather than a means to an end. Indeed, it was generally accepted by participants in the present study that other platforms, notably Facebook, could be more effective for generating the desired interaction between officers and citizens. However, Twitter was seen to be quick to use and much more manageable for officers. Thus, participants drew attention to a fundamental contradiction. Due to their configuration and features, social media platforms other than Twitter (notably Facebook) may offer more effective ways of promoting engagement and citizen participation. Conversely, it is these very features that render the alternative(s) time-consuming for officers and explain why their use is discouraged by constabularies.

It is worth noting at this juncture that a focus on Twitter may be limiting the scope of police communication. This is because there are differences in the reach and demographic profile of the users of different platforms. At the time of writing, Facebook has a much greater reach than does Twitter. To illustrate, research has shown that nearly all citizens who have a profile on social media (96 per cent) have one on Facebook, whereas, in contrast, $30 \%$ of social networkers say they have a Twitter profile (Ofcom, 2014). In addition, there are differences between platforms in respect of the social and demographic characteristics of their users. For example, adult Twitter users are better off and better 
educated than both non-users of social media and users of other platforms (Rainie et al., 2012). Whilst adult users of Facebook vary little by age and gender, adult Twitterers are younger and more likely to be male than female (Ofcom, 2014). In addition, Twitter is poorly used by UK teenagers. For instance, Lenhart (2015) found that thirteen- to seventeen-year olds reported that they used Facebook most frequently (41 per cent), followed by Instagram (20 per cent) and Snapchat (11 per cent). A mere 6 per cent reported that they used Twitter most often. A primary benefit of social media, much discussed in policing discourse, is their presumed ability to attract the youthful audience, which has conventionally been difficult to engage. Any hope of doing so might be undermined by a concentration of communication on Twitter.

In sum, these observations draw attention to how, by concentrating their communication on Twitter, community policing teams may inadvertently be narrowing their reach towards an audience which is dominated by the better educated, better off, younger adult males. These observations also draw attention to the importance of varying communication practices on social media to maximise their potential reach and of being attentive and responsive to the ever-evolving trends in social media use. Social media use is not stable. As Wright (2006: 57) put it 'technology, and people's interaction with it, evolves very, very quickly and things change'. This point was in fact acknowledged by some of the participants in the present study - notably the communications and PR professionals - and as a consequence some constabularies are experimenting with different platforms at the organisational level at least. Nonetheless, community policing teams, and the officers within these teams, largely confine their communications on Twitter with inevitable implications for the reach of their communication practices.

\section{Individual and cultural dynamics}

Lastly, I turn to how individual preferences and cultural features of the police organisation shape the use of social media. Participants drew attention to how some officers and staff are more effective communicators than are others. Whilst it might be that some officers can learn tricks to help them communicate effectively, be it formally or experientially, time and time again participants drew attention to how the successful Twitter accounts were essentially driven by personalities. Indeed, participants indicated that social media use is likely to be valuable only where officers and staff are personally motivated to invest time in generating engaging content. This is in part a function of individual preferences and proficiencies - some officers are naturally better communicators than are others and this applies to offline and online settings. However, participants indicated that officers and staff are differently motivated to engage with social media. There clearly remains some resistance to using social media at the individual officer level. Resistance may be the result of anxiety born of the organisational risks discussed above. Given that participants suggested that senior officers may be more confident in communicating on social media than the rank and file, this is something that might be influenced by rank. This is a slightly ironic position. It is the community policing teams who are expected to use social media to communicate, yet they are comprised of the lowest ranking officers who are little supported in their use of social media. In addition, whilst many officers are no doubt used to using social media in their private lives, using them in their professional lives will represent a change for many. And organisational changes might be resisted. One participant concluded that 'it's about shifting attitudes and getting people to understand 
what it is all about' (INT30). That some officers do not 'understand what it is all about', links to the lacklustre response from (some) chief officers, the lack of clear organisational strategy and the lack of high-quality instruction - all noted above. However, there might well be wider cultural factors at play here, a theme on which I finish.

Many studies have demonstrated that officers are sceptical regarding the view that community engagement should play a prominent role within police work (e.g. Fielding, 1994; Greene, 2000; Herbert, 2001; Bullock, 2014). The rationale for and practices associated with community collaboration are at odds with the rationale of - and practices that officers tend to associate, rightly or wrongly, with - 'real' police work: namely, the pursuit and arrest of criminal suspects and the enforcement of the criminal law (Skolnick, 1966; Fielding, 1994; Greene, 2000). Social media catapults police-citizen engagement from the physical into the virtual realm. This changes the mechanism of delivery, but there is no reason to assume that the attitudes of officers towards the activity itself will be altered. It may well be that social media are resisted by some officers because of wider resistance to the activity social media are seen to represent - citizen engagement. As one participant explained: 'historically there has been some scepticism ... a nice woolly, fluffy thing to do but what is the point?' (INT15). In fact, participants drew attention to how for many officers 'the point' of incorporating social media into police communications is to promote crime control rather than to promote improved relations with citizens. Whilst the official police use of social media is often situated within discourses which foreground community engagement and collaboration, the rank and file may see any benefits rather differently. Certainly when reflecting on their own views, or on the views of others, participants indicated that the organisational benefit of investing officer time in social media is derived less from its potential to promote community-oriented benefits and more from its potential to generate police-oriented benefits: 'it's all about building rapport ... that is just dayto-day stuff but [it] really comes into its own when [you] need something' (INT2). This extract illustrates how the participants in the present study suggested that for many officers the potential to generate information that might promote the enforcement of the criminal law or promote other police relevant outcomes represented the real organisational value of investing in social media. It follows that where social media could be shown to be of value in facilitating law enforcement, its profile was heightened. To illustrate, many participants drew attention to how quantifying the amount of police relevant information that was generated through social media channels, together with the number of arrests and subsequent criminal convictions, was important for demonstrating their value. Social media represent a change in communication style with which some in the organisation are clearly uncomfortable. Moreover, perhaps, they represent a practice that some do not see as a policing priority.

\section{Conclusion}

Social media have been presented as a way of facilitating citizen participation in public policing. British constabularies have long sought but often struggled to engage citizens, and social media have been seen as a tool for circumventing past problems and providing new mechanisms through which to present the institution as open, transparent and democratic. This article adds to the growing body of work which indicates that for all the potential of social media, much output is one-way and fails to facilitate interaction between constabularies and citizens. We can say with some confidence that whilst 
omnipresent, social media are not inevitably transformative. This article considered the factors which shape the police use of social media in order to shed light on why they may not be transforming police communicative practices in the ways that have been mooted.

Whilst technology is oft-promoted as a way of increasing police effectiveness and efficiency, technological advances in policing have little changed the character of policing or its effectiveness (Manning, 1992, 2001, 2008; Chan, 2003). Policing remains a lowtechnology occupation, technology is likely to be underutilised by officers, and police technologies tend to reproduce existing orders rather than transform them (Manning, 2008). Pertinently, technology shapes organisations and is shaped by them, and, in this sense, the introduction of a new technology is merely the beginning of a 'technological drama' which involves processes of normalisations, adjustment, reconstitution and reintegration (Chan, 2003: 673). In this vein, this article has drawn attention to how the transformative potential of social media has been mediated by the ways that organisations and individuals within them interpret the technologies and incorporate them into their day-to-day routines. As social media are introduced into constabularies their transformative potential are shaped by the organisational environment. This article has demonstrated that this can be understood in terms of an interplay between technological, organisational and individual and cultural dynamics. From the standpoint of police leaders, to the approach taken to organisational risk, to the nature of strategic direction, to the quality of training and guidance, to the availability and nature of police ICT, to the peculiarities of the dominant social media platforms utilised, to the attitudes of rank and file officers, a wide range of leadership, managerial, technological and cultural dynamics have played a role in shaping what has been achieved. Taken together then, these dynamics demonstrate that social media represent not just a technological revolution but an organisational and cultural revolution that must be negotiated by organisations and individuals.

This article demonstrates that social media have not been absorbed into police communication practices in a straightforward way. The scepticism and risk aversion of some leaders and the apathetic response from some officers indicate that there are at times conflicts between organisational needs and expectations and the conditions required to promote effective communication on social media (see also Macnamara and Zerfass, 2012). Failure to provide leadership, strategic guidance or to develop an infrastructure (including a technological infrastructure) to support social media use by officers indicates that the role social media should be playing within police communications is not clear and that the degree to which utilising them is seen as an organisational priority is questionable. Furthermore their transformative potential appears to have been muted by the organisational upheavals and conflicts that social media have generated and the ways that constabularies and officers therein have responded. Social media are undoubtedly altering the ways that constabularies and officers communicate with citizens. However, embedding social media into police communications is challenging and the application of the technologies themselves will not bring about the wider organisational and cultural changes needed to transform police-citizen communications.

\section{Note}

1 Known as POLKA 'Police OnLine Knowledge Area'. 


\section{References}

Association of Chief Police Officers (ACPO) (2013) Guidelines on the Safe Use of the Internet and Social Media by Police Officers and Police Staff, London: ACPO.

Ashby, M. (n.d.) 'Statistics for UK police on Twitter', http://lesscrime.info/policetweets/stats/ (accessed 21/03/2107).

Avery, E. and Graham, M. (2013) 'Political public relations and the promotion of participatory, transparent government through social media', International Journal of Strategic Communication, 7, 4, 274-91.

Barlow, D. E. and Barlow, M. H. (1999) 'A political economy of community policing', Policing: An International Journal of Police Strategies and Management, 22, 4, 646-74.

Brainard, L. A. and J. G. McNutt (2010) 'Virtual government and citizen relations', Administration and Society, 42, 7, 836-58.

Bullock, K. (2014) Citizens, Communities and Crime Control, Basingstoke: Palgrave.

Chadwick, A. and May, C. (2003) 'Interaction between states and citizens in the age of the internet: "eGovernment" in the United States, Britain, and the European Union', Governance: An International Journal of Policy, Administration, and Institutions, 16, 2, 271-300.

Chadwick, A. (2009) 'Web 2.0: new challenges for the study of e-democracy in an era of informational exuberance', I/S: A Journal of Law and Policy, 5, 1, 9-42.

Chan, J. (2003) 'Police and new technologies', in T. Newburn (ed.), The Handbook of Policing, Cullompton: Willan.

Chromy, J. (2008) 'Snowball sampling', in P. Lavrakas (ed.), Encyclopaedia of Survey Research Methods, London: Sage.

COPS (2013) Social Media and Tactical Considerations for Law Enforcement, Washington: US Department of Justice, http://www.policeforum.org/assets/docs/Free_Online_Documents/Technology/social\%20 media $\% 20$ and $\% 20$ tactical\%20considerations $\% 20$ for $\% 20$ law $\% 20$ enforcement $\% 202013$.pdf (accessed 24.01.2016).

Crump, J. (2011) 'What are the police doing on Twitter? Social media, the police and the public', Policy and Internet, 3, 4, Article 7, www.policyandinternet.org (accessed 07.09.2015).

Di Gennaro, C. and Dutton, W. (2006) 'The internet and the public: online and offline political participation in the United Kingdom', Parliamentary Affairs, 59, 2, 299-313.

Elliott, R. and Nicholls, J. (1996) 'It's good to talk: lessons in public consultation and feedback', Police Research Series Paper 22, London: Home Office.

Ellison, N. and Hardey, M. (2014) 'Social media and local government: citizenship, consumption and democracy', Local Government Studies, 40, 1, 21-40.

Fielding, N. (1994) 'Cop canteen culture', in T. Newburn and E. Stanko (eds.), Just Boys Doing Business? Men Masculinities and Crime, London: Routledge.

Fink, S. and Zerfass, A. (2010) Social Media Governance 2010: How Companies, the Public Sector, and NGOs Handle the Challenge of Transparent Communication on the Internet, Research Report, Leipzig, Germany: University of Leipzig and Fink \& Fuchs PR, http://www.ffpr.de/ newsroom/wp-content/uploads/2012/08/Social-Media-Governance-2010-Results-final.pdf (accessed 25.05.2015).

Goldsmith, A. (2015) 'Disgracebook policing: social media and the rise of police indiscretion', Policing and Society: An International Journal of Research and Policy, 25, 3, 249-67.

Greene, J. (2000) 'Community policing in America: changing the nature, structure, and function of the police, policies, processes, and decisions of the criminal justice system', Community Policing in America, 3, 299-370, https://www.ncjrs.gov/criminal_justice2000/vol_3/03g.pdf (accessed 07.06.2015).

Grimmelikhuijsen, S. and Meijer, A. (2015) 'Does Twitter increase perceived police legitimacy?', Public Administration Review, 75, 4, 598-607.

Halavais, A. (2013) 'Structure of Twitter: social and technical', in K. Weller, A. Bruns, J. Burgess, M. Mahrt and C. Puschmann (eds.), Twitter and Society, Oxford: Peter Lang. 
Harfield, C. (1997) 'Consent, consensus or the management of dissent? Challenges to community consultation in a new policing environment', Policing and Society, 7, 4, 271-89.

Herbert, S. (2001) 'Policing the contemporary city: fixing broken windows or shoring up neo-liberalism?', Theoretical Criminology, 5, 4, 445-66.

Hughes, G. (1994) 'Talking cop shop? A case study of police community consultative groups in transition', Policing and Society, 4, 4, 253-70.

Jones, T. and Newburn, T. (2001) 'Widening access: improving police relations with hard to reach groups', Police Research Series Paper 138, London: Home Office.

Jones, Q., Ravid, G. and Rafaeli, S. (2004) 'Information overload and the message dynamics of online interaction spaces', Information Systems Research, 15, 2, 194-210.

Joyce, E. and Kraut, R. E. (2006) 'Predicting continued participation in newsgroups', Journal of ComputerMediated Communication, 11, 3, 723-47.

Keith, M. (1988) 'Squaring circles? Consultation and "inner city" policing', New Community, 15, 1, 6377.

Lea, J. and Young, J. (1993 [1984]) What Is to Be Done about Law and Order, London: Pluto Press.

Lee, M. and McGovern, A. (2013) 'Force to sell: policing the image and manufacturing public confidence', Policing and Society: An International Journal of Research and Policy, 23, 2, 103-24.

Lenhart, A. (2015) Teens, Social Media and Technology Overview 2015, Washington, DC: Pew Research Centre, http://www.pewinternet.org/2015/04/09/teens-social-media-technology-2015/ (accessed 04.06.2015).

Lieberman, J., Koetzle, D. and Sakiyama, M. (2013) 'Police departments' use of Facebook: patterns and policy issues', Police Quarterly, 16, 4, 438-62.

Lipschultz, J. (2015) Social Media Communication: Concepts, Practices, Data, Law and Ethics, Abingdon: Routledge.

Loader, B. and Mercea, D. (2011) 'Networking democracy?', Information, Communication and Society, 14, 6, 757-69.

Loader, B., Vromen, A. and Xenos, M. (2014) 'The networked young citizen: social media, political participation and civic engagement', Information, Communication and Society, 17, 2, 143-50.

Loader, I. (1999) 'Consumer culture and the commodification of policing and society', Sociology, 33, 2, 373-92.

Loader, I. and Walker, N. (2001) 'Policing as a public good: reconstituting the connections between policing and the state', Theoretical Criminology, 5, 1, 9-35.

London Assembly (2013) Smart Policing: How the Metropolitan Police Service can Make Better Use of Technology, London: London Assembly, https://www.london.gov.uk/sites/ default/files/gla_migrate_files_destination/Police\%20technology\%20report\%20-\%20Final\%20version.pdf (accessed 21.03.2017).

Macnamara, J. and Zerfass, A. (2012) 'Social media communication in organizations: the challenges of balancing openness, strategy, and management', International Journal of Strategic Communication, 6, 4, 287-308.

Maguire, E. and Wells, W. (2002) 'Community policing as communication reform', in H. Giles (ed.), Law Enforcement, Communication, and Community, Amsterdam: John Benjamins Publishers.

Manning, P. (1991) 'Community policing as drama of control', in J. Greene and S. Mastrofski (eds.), Community Policing: Rhetoric or Reality, New York: Praeger.

Manning, P. (1992) 'Information technology and the Police', in M. Tonry and N. Morris (eds.), Modern Policing, Chicago, IL: Chicago University Press.

Manning, P. (2001) 'Technology's ways: information technology, crime analysis and the rationalizing of policing', Criminology and Criminal Justice, 1, 1, 83-103.

Manning, P. (2008) The Technology of Policing: Crime Mapping, Information Technology and the Rationality of Crime Control, New York: New York University Press.

McLaughlin, E. (2005) 'Forcing the issue: new labour, new localism and the democratic renewal of police accountability', The Howard Journal, 44, 5, 473-89. 
Myhill, A., Yarrow, S., Dalgleish, D. and Docking, M. (2003) 'The role of police authorities in public engagement', Home Office Online Report 37/03, London: Home Office.

Ofcom (2014) Adults' Media Use and Attitudes Report 2014, London: Ofcom, https://www. ofcom.org.uk/_data/assets/pdf_file/0020/58223/2014_adults_report.pdf (accessed 23.10.2016).

Parsons, J. (2008) 'Key informant interviewing', in P. Lavrakas (ed.), Encyclopaedia of Survey Research Methods, London: Sage.

Police Foundation (2014) The Briefing - Police Use of Social Media, London: Police Foundation, http://www.police-foundation.org.uk/uploads/catalogerfiles/police-use-of-social-media/Social_ media_briefing_FINAL.pdf (accessed 10.05.2015).

Preece, J., Nonnecke, B. and Andrews, D. (2004) 'The top 5 reasons for lurking: improving community experiences for everyone', Computers in Human Behavior, 20, 2, 201-23.

Rainie, L., Smith, A., Lehman Schlozman, K., Brady, H. and Verba, S. (2012) Social Media and Political Engagement, Washington, DC: Pew Centre, http://www.pewinternet.org/files/old-media// Files/Reports/2012/PIP_SocialMediaAndPoliticalEngagement_PDF.pdf (accessed 07.09.2015).

Scarman, I. (1981) The Brixton Disorders 10-12 April 1981, London: HMSO.

Schmidt, J. (2013) 'Twitter and the rise of personal publics', in K. Weller, A. Bruns, J. Burgess, M. Mahrt and C. Puschmann (eds.), Twitter and Society, Oxford: Peter Lang.

Schneider, C. (2016) 'Police presentational strategies on Twitter in Canada', Policing and Society: An International Journal of Research and Policy, 16, 2, 129-47.

Sklansky, D. (2005) 'Police and democracy', Michigan Law Review, 103, 7, 1699-830.

Skolnick, J. H. (1966) Justice without Trial: Law Enforcement in Democratic Society, New York: Macmillan.

Stoker, G. (2006) Why Politics Matters: Making Democracy Work, Basingstoke: Palgrave.

Stratta, E. (1990) 'A lack of consultation', Policing, 6, 3, 523-48.

Tanner, S. and Meyer, M. (2015) 'Police work and new "security devices": a tale from the beat', Security Dialogue, 46, 4, 384-400.

Whiteley, P. (2012) Political Participation in Britain: The Decline and Revival of Civic Culture, Basingstoke: Palgrave Macmillan.

Wright, S. (2006) 'Electrifying democracy? 10 years of policy and practice', Parliamentary Affairs, 59, 2, $236-49$. 